\title{
PALAEOPEDOGENIC FEATURES AND THEIR PALAEOCLIMATOLOGICAL SIGNIFICANCE FOR THE NEVREMONT FORMATION (LOWER GIVETIAN), THE NORTHERN ARDENNES, BELGIUM
}

\section{N. MOLENAAR}

Comparative Sedimentology Division, Institute for Earth Sciences, State University of Utrecht, Budapestlaan 4, Utrecht (The Netherlands)

(Received September 19, 1983; revised version accepted March 13, 1984)

\section{ABSTRACT}

Molenaar, N., 1984. Palaeopedogenic features and their palaeoclimatological significance for the Nèvremont Formation (Lower Givetian), the northern Ardennes, Belgium. Palaeogeogr., Palaeoclimatol., Palaeoecol., 46: 325-344.

The lower member of the Nèvremont Formation is characterized by the frequent occurrence of pedogenic features, which suggest intermittent exposure of the fluvial depositional environment.

The evidence for pedogenesis comprises horizons of calcite glaebules and nodular calcrete, haematite segregation, resulting in pronounced colour mottling, and the formation of palaeosolic root-horizons with root tubes, cutanic features, burrows and striotubules.

Based upon the presence of these features, it is suggested that the climate was semiarid. The source area of the quartz-rich parent clastic sediment was presumably subjected to intensive chemical weathering, resulting in mature quartzose sediments, with illite and kaolinite as dominant clay minerals.

\section{INTRODUCTION}

Descriptive studies of the Devonian sediments in the northern Belgian Ardennes have resulted in a well-established stratigraphic framework (Coen-Aubert, 1974). However, little is known of the depositional environments, especially for the Middle Devonian. Sedimentation during the Early Givetian was probably strongly influenced by the presence of the London-Brabant Massif, situated north of the Dinant Basin, and perhaps by the Stavelot Massif (Tsien, 1974), situated southeast of the Vesdre Basin. The first was a pronounced high during most of post-Caledonian Paleozoic time (Coen-Aubert, 1974; Ziegler, 1978). During the earliest Givetian this high probably formed a landmass that was part of the Old Red Continent. 
The Givatian in the northeastern part of the Dinant Basin and the western part of the Vesdre Basin (Fig.1) can be subdivided into two formations (Fig.2), the lowest being the Nèvremont Formation (Coen-Aubert, 1974). The lower part of the Nèvremont Formation consists of quartzose clastics, the upper part is composed of limestones or dolomites. The lower member of the Nèvremont Formation, which will be referred to as Member 1, is composed of a variegated clastic sequence. This sequence consists of interbedded red, grey and mottled conglomerates, arenites and clastic wackes. The composition is predominantly quartzose, although carbonate grains may be an important constituent in the upper part of Member 1.

The aim of this paper is to establish a depositional environment for the lower part of the Nèvremont Formation by means of interpretation of early diagenetic features. Furthermore, evidence will be given for the presence of pedogenic features comparable to those in recent soils. Palaeosols might be expected since terrestrial plants developed during the Early Devonian. How ever, with the exception of the description of Old Red Sandstone calcretes by Allen (1974) and Leeder (1975), few Devonian palaeosols have been described so far (McPherson, 1979; Ortlam, 1980).

Samples were studied from exposures at Barse-Vierset (1), Tilff (2), Prayon (3), Trooz-Fraipont (4), and Les Mazures (5) (Fig.1) by means of petrographical study of some 100 thin sections, X-ray diffraction study and scanning electron microscopy.

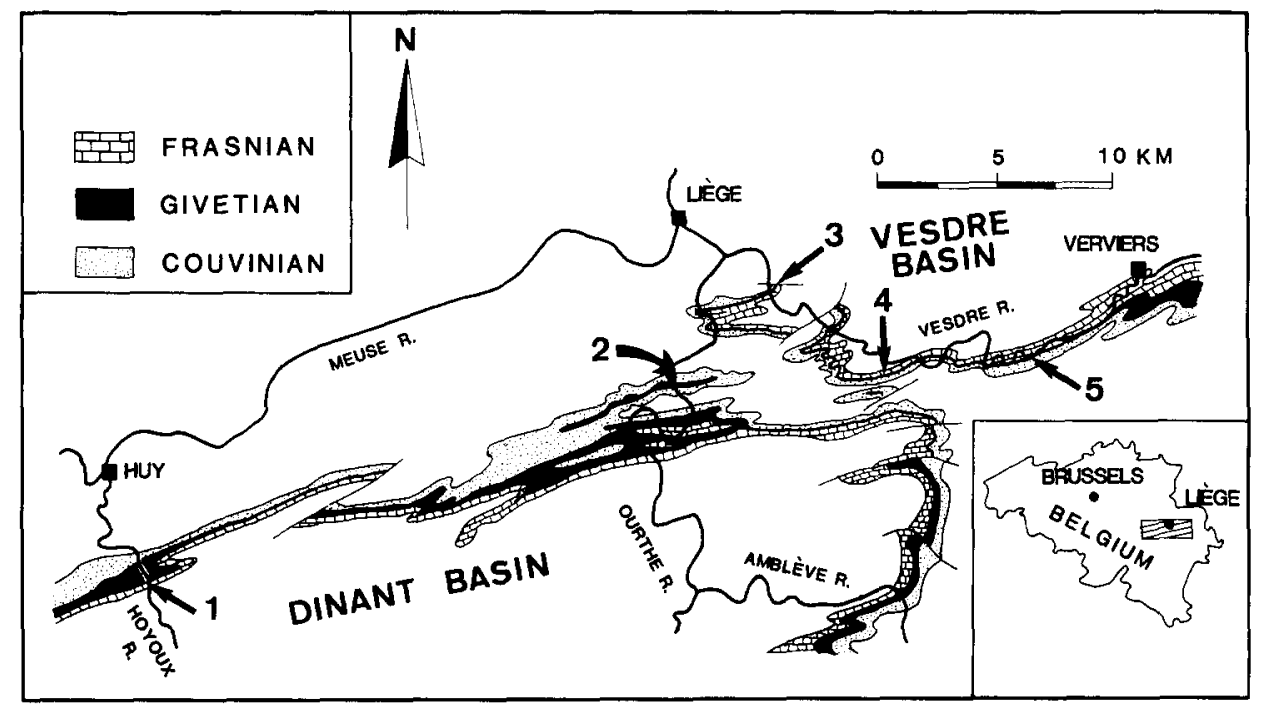

Fig.1. Sample locations and general distribution of the Couvinian, Givetian and Frasnian in the northern part of the Dinant Basin and the western part of the Vesdre Basin. Thickness of Member 1 or the exposed part of Member 1 ranges from 4 to $19 \mathrm{~m}$. ( $1=$ BarseVierset; $2=$ Tilff; $3=$ Prayon; $4=$ Trooz-Fraipont; $5=$ Les Mazures.) 


\begin{tabular}{|c|c|c|c|c|}
\hline \multicolumn{4}{|c|}{ AGE/FORMATION } & LITHOLOGY \\
\hline 崖畐々 & \multicolumn{3}{|c|}{ FRASNIAN } & $\begin{array}{c}\text { CYCLIC BIOSTROMAL } \\
\text { LIMESTONES } \\
\text { (BIOSPARITES-MICRITES) }\end{array}$ \\
\hline \multirow{5}{*}{ 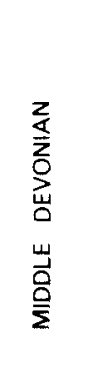 } & \multirow{4}{*}{ 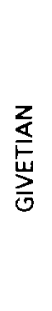 } & & ROUX Fm. & DOLOMITES \\
\hline & & \multirow{3}{*}{ 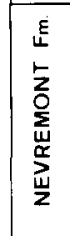 } & MEMBER 3 & $\begin{array}{c}\text { DOLOMITES, } \\
\text { SILICICLASTIC DOLOMITES }\end{array}$ \\
\hline & & & MEMBER 2 & $\begin{array}{l}\text { (PELLETOIDAL-FENESTRAL) } \\
\text { LIMESTONES, } \\
\text { SILICICLASTIC DOLOMITES }\end{array}$ \\
\hline & & & MEMBER 1 & $\begin{array}{l}\text { VARIEGATED ARENITES } \\
\text { AND CONGLOMERATES }\end{array}$ \\
\hline & \multicolumn{3}{|c|}{ COUVINIAN } & $\begin{array}{l}\text { RED SHALES, ARENITES } \\
\text { AND CONGLOMERATES }\end{array}$ \\
\hline
\end{tabular}

Fig.2. General stratigraphy and lithology (after Kasig and Neumann-Mahlkau, 1969; Coen-Aubert, 1974; and measured sections (Fig.1)).

\section{DESCRIPTION AND INTERPRETATION}

\section{Host rock}

The clastics constituting Member 1 in the studied exposures are quartzarenites or lithic arenites, conglomerates, and wackes, in descending order of frequency. X-ray diffraction studies show that illite and kaolinite are the main clay minerals, occurring in various proportions, while chlorite occurs in minor amounts. The clastics build up sheet-like or lenticular layers, consisting internally of broad, shallow scour and fill deposits with low-angle cross lamination or horizontal lamination. Locally, they may be arranged in thinning-upward and fining-upward sequences. The siliciclastics were probably eroded from rocks cropping out in the London--Brabant Massif, as indicated by the presence of some tourmaline-quartzite clasts (Kasig and NeumannMahlkau, 1969).

The sediments are lithified predominantly by quartz cementation in the quartzose terrestrial deposits, or by both quartz and calcite cementation in the presumably lacustrine and shallow marine clastics (Molenaar, in prep.). The cementation occurred partly penecontemporaneously, and partly during burial diagenesis, as witnessed by, respectively, the lack of or presence of compactional features. Locally haematite may form a cementing agent and a pigment.

The sediments of Member 1 possess a high mineralogical maturity. Framework components of the arenites are predominantly quartz. Lithic fragments, such as phyllitic-clayey rock fragments, siltite, arenite and metaquartzite rock fragments and carbonate (bio)clasts occur in varying percentages. These carbonate (bio)clasts occur in several layers in the upper part of the sequence. The fossil content points to some lacustrine intercalations and (reworked) 


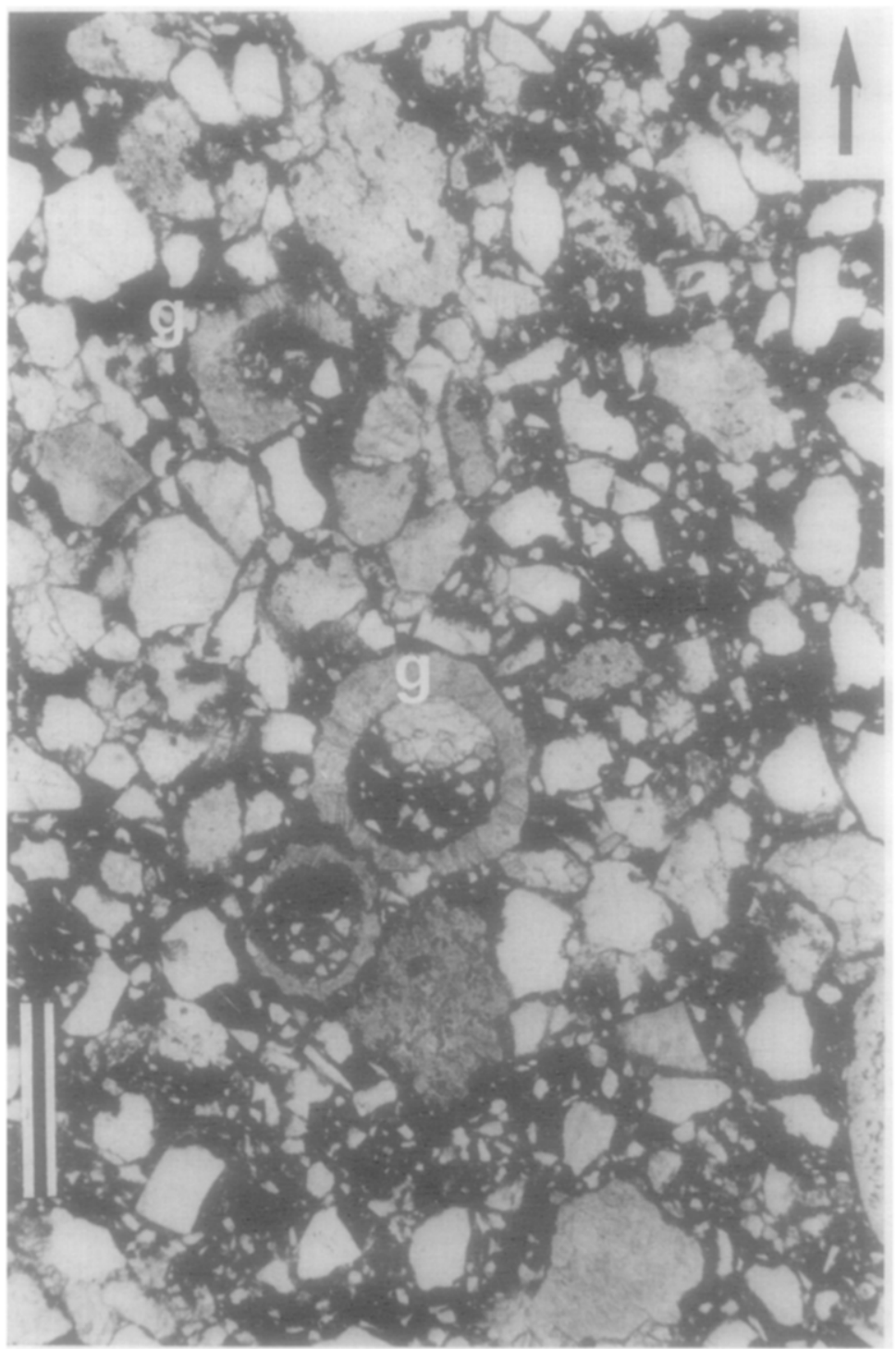

Fig.3. Slightly reworked gyrogonites $(G)$ with internal geopetal sediment and geopetal accumulation of matrix on top of clastic grains. The arrow indicates the stratigraphic facing. The mechanically infiltrated matrix is iron-rich. The sediment is a sublithic arenitewacke from a lacustrine intercalation with some carbonate clasts and calcite cement. Sample TF54, Location 4. Plane-polarized light. Scale bar $=1 \mathrm{~mm}$.

marine incursions towards the top of Member 1. Gyrogonites, i.e. calcified female fructifications of charophytes (Fig.3), and peloids indicate lacustrine conditions, whilst wom bioclasts, brachiopod fragments and fossiliferous limestone fragments are relicts of the marine incursions. The quartz grains may be second cycle, because of the presence of some worn overgrowths. 
Quartz grains show an embayed surface in several wackes, probably caused by superficial dissolution. The roundness of the quartz grains varies from very angular to well rounded, or it may be totally obscured by quartz overgrowths or marginal replacement by ferric oxides. Sorting also displays a large range. Arenites are well sorted to very poorly sorted, while the conglomerates are nearly always poorly or very poorly sorted. This variable textural immaturity and the range in mineralogical maturity (mature to submature) were probably caused by extensive mechanical mixing of the sediments. Vadose diagenesis was active during these relatively long periods of slow sedimentation or pauses in sedimentation, as indicated by the presence of the various pedological features described in this paper. Apart from roots and plant fragments, further fossil remains are scarce.

\section{Root channels}

Dispersed throughout the conglomeratic and arenitic sediments are tubular structures or systems of branching tubes, which are interpreted as being caused by root penetrations. These tubes are empty or they may still be filled with organic material, now carbonized. The former root tubes are arranged in horizons approximately parallel to the bedding, and probably mark the palaeopedomorphic surfaces. They have been traced over a distance of several hundred meters near section 4 . The root-tube horizons at several stratigraphic levels in sections 1 and 4 indicate a former vegetation-cover.

Root tubes, with a maximum diameter of $2 \mathrm{~cm}$, formed a path along which other processes occurred preferentially. One of these processes was the segregation of iron compounds. This resulted in bleached zones along the channels and dark-red iron enrichment zones or neoferrans, which show distinct inner margins towards the channel and vague outer margins. These bleached zones and neoferrans are clearly visible in Fig.4.

\section{Burrows and striotubules}

In several samples the sediment is disturbed by striotubules (Fig.5). These are striated (animal) burrows. Similar features have been described by Buurman (1980). Visibility of these structures is sometimes enhanced by iron and manganese oxides separations. In several samples burrowing caused clearly visible mixing of primary clayey and sandy laminae. These burrows may be partly filled with gypsum or baryte.

\section{Clay illuviation}

Illuviation cutans, composed of clay-sized material, are common in many of the sandstones as well as the conglomerates. However, in the conglomerates and the wackes this feature seems to be restricted to former permeable channels, because of the presence of a primary, i.e. detrital, clay matrix in 


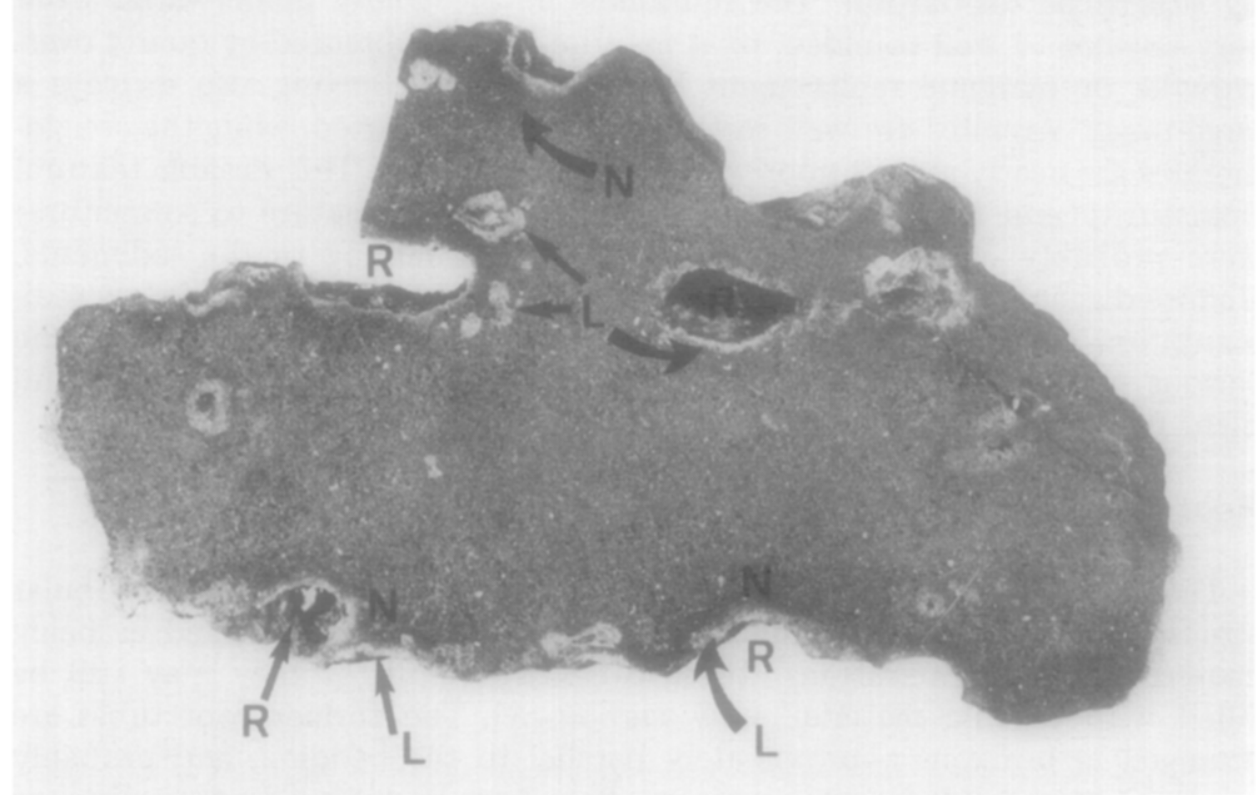

Fig.4. Photograph of hand sample showing root channels $(R)$, light brown leached zones $(L)$, brown neoferrans $(N)$, and greyish brown porous arenite with clay cutans dispersed throughout the sediment. Sample TF60, Location 4 . Sample is $16 \mathrm{~cm}$ long and $9 \mathrm{~cm}$ high.

many conglomerates and associated low porosity. Apart from some detrital clay in the arenites, occurring as matrix and/or clasts, clay may be present around grains and bordering vugs. Clay flakes, predominantly illite and kaolinite, are aligned with their (001) planes parallel to grain boundaries and vug boundaries (Fig.6B, C), forming a birefringent fabric, i.e. a clay cutan (Fig.6A). Permeability may be greatly reduced, creating an impermeable layer or horizon.

In vugs and larger pores these cutans, referred to as void argillans (Brewer, 1964), are often mammilated, as variations in thickness of the cutan result in curved cutanic surfaces. Owing to compaction in the wackes, argillans (presumably former void argillans) were squeezed into irregular masses still possessing a birefringent fabric. In other cases the irregular clayey masses are compacted clay-filled burrows or clay lenses between sand-filled burrows.

Clay-cutans are the result of mechanical infiltration in a formerly porous sediment (Teruggi and Andreis, 1971; Brewer, 1972; Walker et al., 1978). Above or near the former watertable or above impermeable layers the claysized material was flushed in and remained in the pores when downward flux with clay particles in suspension stagnated and the water evaporated.

Clay illuviation is a process restricted to the vadose zone or the zone of fluctuating groundwater table (Teruggi and Andreis, 1971; Walker et al., 


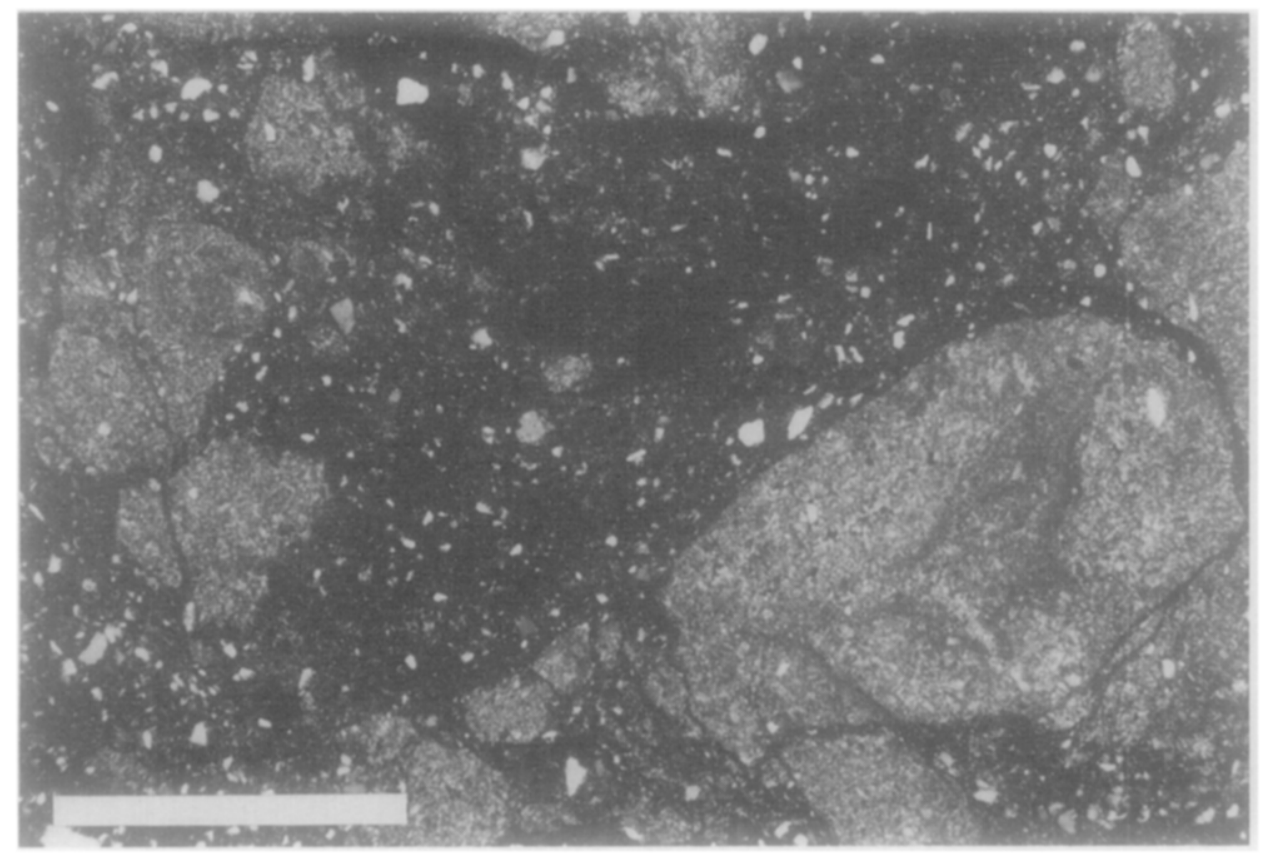

Fig.5. Photomicrograph from thin section showing a striotubule and some calcrete glae bules. Glaebules seem to be displaced somewhat by the burrowing agent. Sample TF88, Location 4. Crossed nicols. Scale bar $=1 \mathrm{~mm}$.

1978). Clay cutans are very frequently observed in paleosols (Terugi and Andreis, 1971). However, soil formation is not a prerequisite, since they may also form in (semi) arid regions (Walker et al., 1978). Their relationship with palaeosols is sometimes clearly demonstrated by former root tubes with clay cutans (Fig.7) or by the presence of other pedogenic features. The thickness of the cutans is probably mainly dependent on the diameter of the connections between pores, which is a function of sorting and packing of the sediment. Since the distribution of sorting and packing is inhomogeneous, thicknesses of cutans display a similarly irregular distribution. The settling of clay particles is likely to have obstructed small pore connections. This caused the stop of the downward flux. In this case, porosity would be partly preserved. The thickness of the cutans is probably also affected by the duration of the interruption of sedimentation. A long interruption, and thus a long residence in the vadose or uppermost phreatic zone, would allow more clay to be moved downward. In general, this occurs in conjunction with the formation of palaeosols, since palaeosol development typically represents a major break in the sedimentation.

Whenever clay cutans were thick enough, and completely enclosed the framework components, they prevented later cementation (Heald and Larese, 1974). This resulted in a friable and porous sediment. 

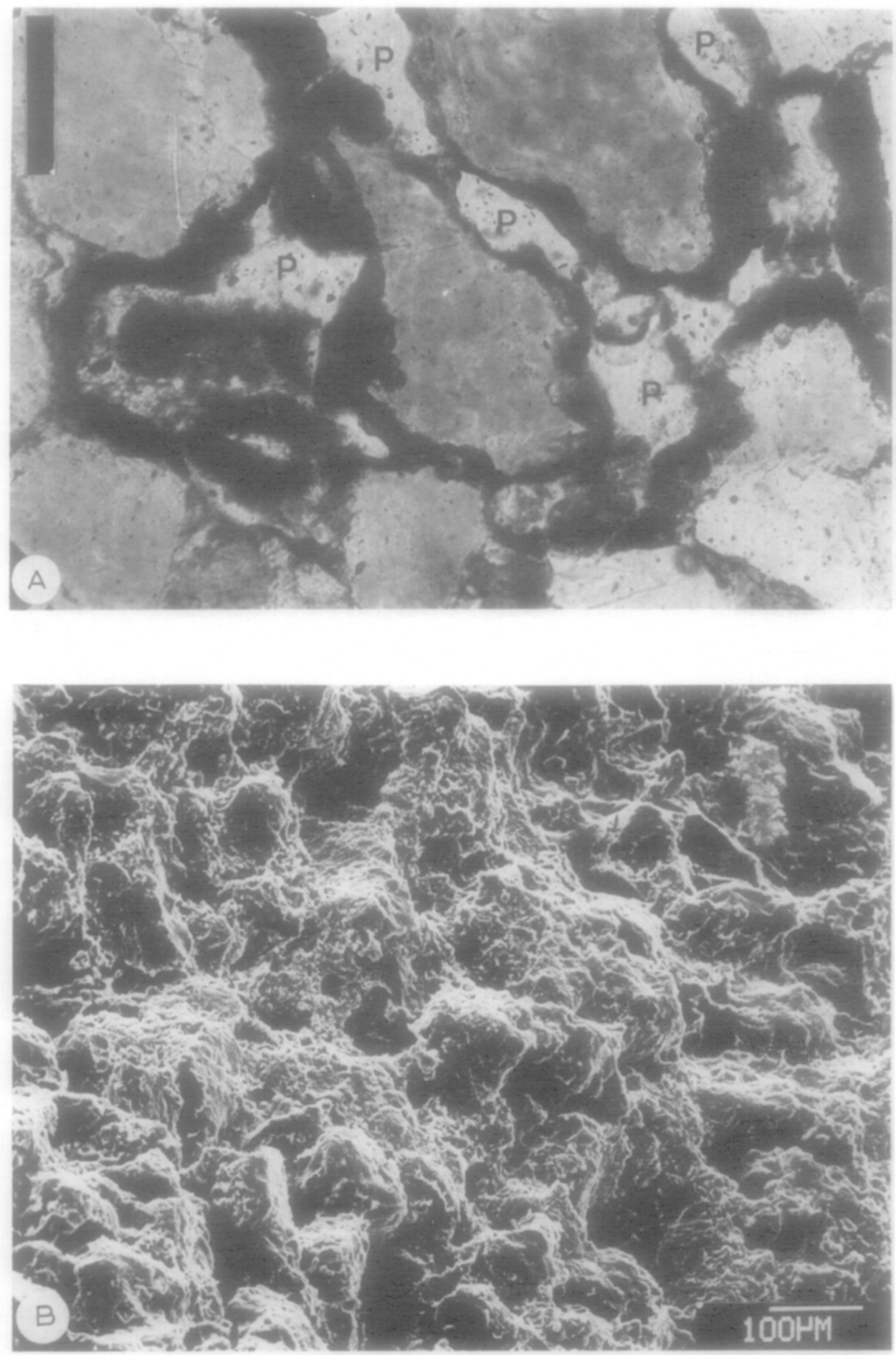


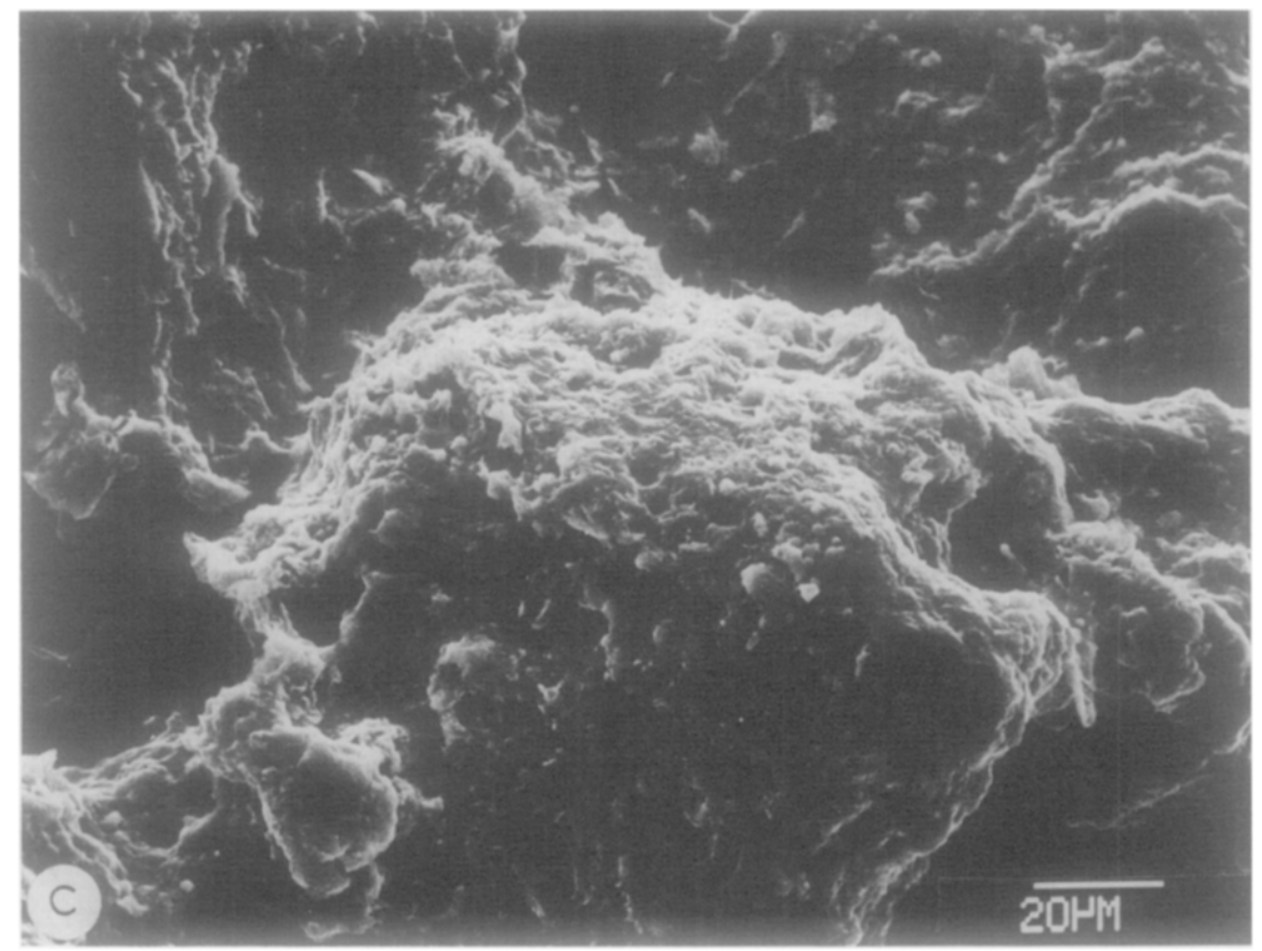

Fig.6. Example of arenite with mechanically infiltrated clay forming clay cutans. A. Oriented birefringent clay around very angular quartz clasts, one with worn overgrowth, and mammilated argillans inside and bordering larger vugs with reduced primary porosity (P). Partly crossed nicols. Sample TF60, Location 4. Scale bar $=0.1 \mathrm{~mm}$. B. Scanning electron microphotograph of the same sample showing the clay cutans. Secondary electron image. C. Detail of $6 \mathrm{~B}$ : oriented clay platelets parallel to the quartz grain surface. Secondary electron image.

\section{Haematite}

Iron (oxi)hydrate compounds, now converted to haematite as identified by XRD, were not present in the sediment at the time of deposition, apart from some haematitic clasts in conglomerates and as clay-sized matrix in some wackes at the top of fining-upward sequences. Iron compounds are manganese-rich as is shown by SEM observations.

The iron and manganese (oxi)hydrates were also flushed in mechanically. Mechanical infiltration usually took place concurrently with clay infiltration, which occurred in at least two phases: one phase penecontemporaneously and a second phase after partial quartz cementation. The infiltrated, i.e. illuviated, iron and manganese compounds occur in cutans around framework grains, dispersed throughout the sediment or along permeable channels. They form ferrans (as a separate phase) or ferri-argillans (together with clay minerals) (Brewer, 1964). Locally, the iron and manganese compounds may 


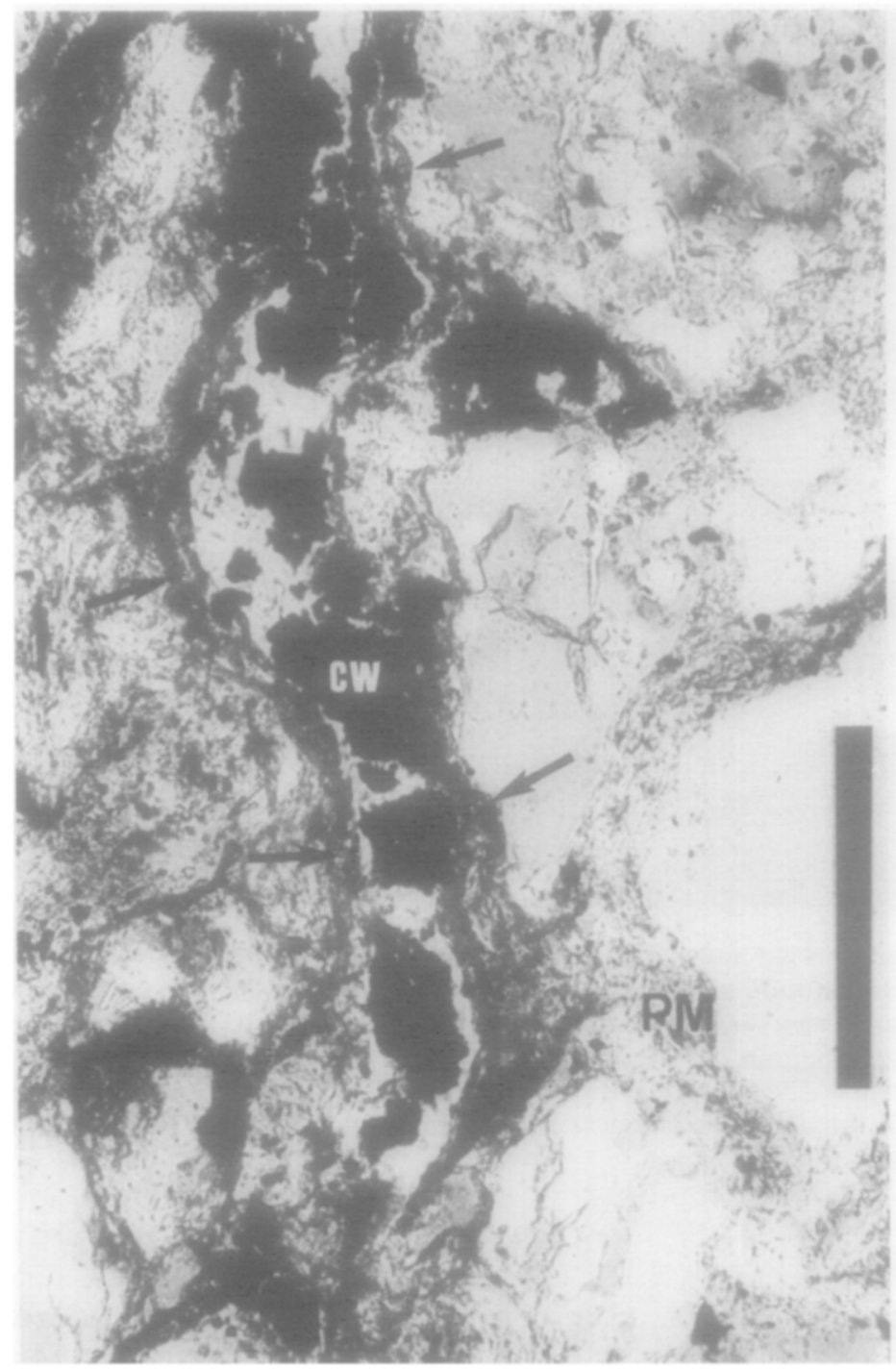

Fig.7. Photomicrograph of a root tube with carbonized wood fragments $(C W)$ and clay cutans (indicated with arrows) around the former rootlet in an arenite with some primary clay matrix $(P M)$. Plane-polarized light. Sample B23, Location 1 . Scale bar $=1 \mathrm{~mm}$.

thus form the cementing material, partly or completely filling the pores. The occurrence of geopetal structures indicates the mechanical mode of infiltration (Fig.3). Frequently, both mechanical infiltration and chemical infiltration and/or redistribution (gleying) are controlled by the presence of permeable channels such as root tubes or burrows, causing a mottled distribution of clay and haematite in the sediment.

However, iron and manganese infiltration cannot be attributed to pedogenic processes with certainty, since infiltration could have occurred above 
the water table regardless of the presence of a soil. The only prerequisite for this process is a lowered groundwater level.

Apart from detrital supply, intrastratal solution of ferro-magnesian minerals in a chemically immature sediment is capable of introducing iron-manganese compounds into the sediment, and of causing red colouration (Walker, 1967; Morad, 1983). However, because of the high mineralogical maturity of the sediments of Member 1, and the almost total lack of ferro-magnesian mineral grains and authigenesis of clay-minerals, which would be a result of intrastratal solution, this can be ignored as a source for iron-manganese compounds. Infiltration probably accounts for (nearly) all the iron and manganese compounds.

\section{Mottling and ferric glaebules}

Colour mottling is a common feature in many of the arenites and wackes. They occur as light grey to greenish mottles, frequently vermicular, within a reddish matrix. The mottles may have either diffuse or distinct boundaries. In several samples they are clearly associated with former root tubes, i.e. a bleached zone around the tube.

After infiltration, the iron and manganese (oxi)hydrates were subjected to two modifications: redistribution (gleying), and recrystallization, causing red colouring. Redistribution of the iron and manganese compounds was a fairly common process in the wackes as well as in the arenites. This resulted in a pronounced colour mottling, i.e. light grey to greenish greyish spots caused by removal of these compounds. Especially along preferred water channels, such as burrows and former root tubes redistribution and consequently mottling was very frequent. Figure 4 shows an example of the leaching and the resulting bleached zones around former root tubes, with dark colored neoferrans-mangans.

Segregation processes, i.e. the redistribution of the iron-manganese compounds, were caused by pseudogleying (Buurman, 1980). Pseudogleying occurs above or near a low groundwater level. Periodic wetting of the soil occurred predominantly downward along permeable channels, such as root tubes and burrows. The greater part of the soil above this low groundwater level was thus oxidized, while wetted channels periodically possessed a reducing micro-environment (Buurman, 1980). In these channels, iron and manganese compounds became reduced and thus soluble. Leaching and eventual reprecipitation in the oxidized parts of the soil was the consequence (Fig.4). The pseudogleying resulted in a red matrix with leached greyish spots.

In some samples segregation processes caused concentration of the iron (and manganese) oxides in small massive ferric nodules (Fig.10), often combined with calcite, forming compound calcite-ferric glaebules (Figs.8A, B, C and Fig.10). The ferric nodules do not possess an internal fabric and mostly have a similar or slightly lower content of clastic grains as compared to the matrix. The size of the ferric glaebules in the wackes (up to $1 \mathrm{~mm}$ ) shows 

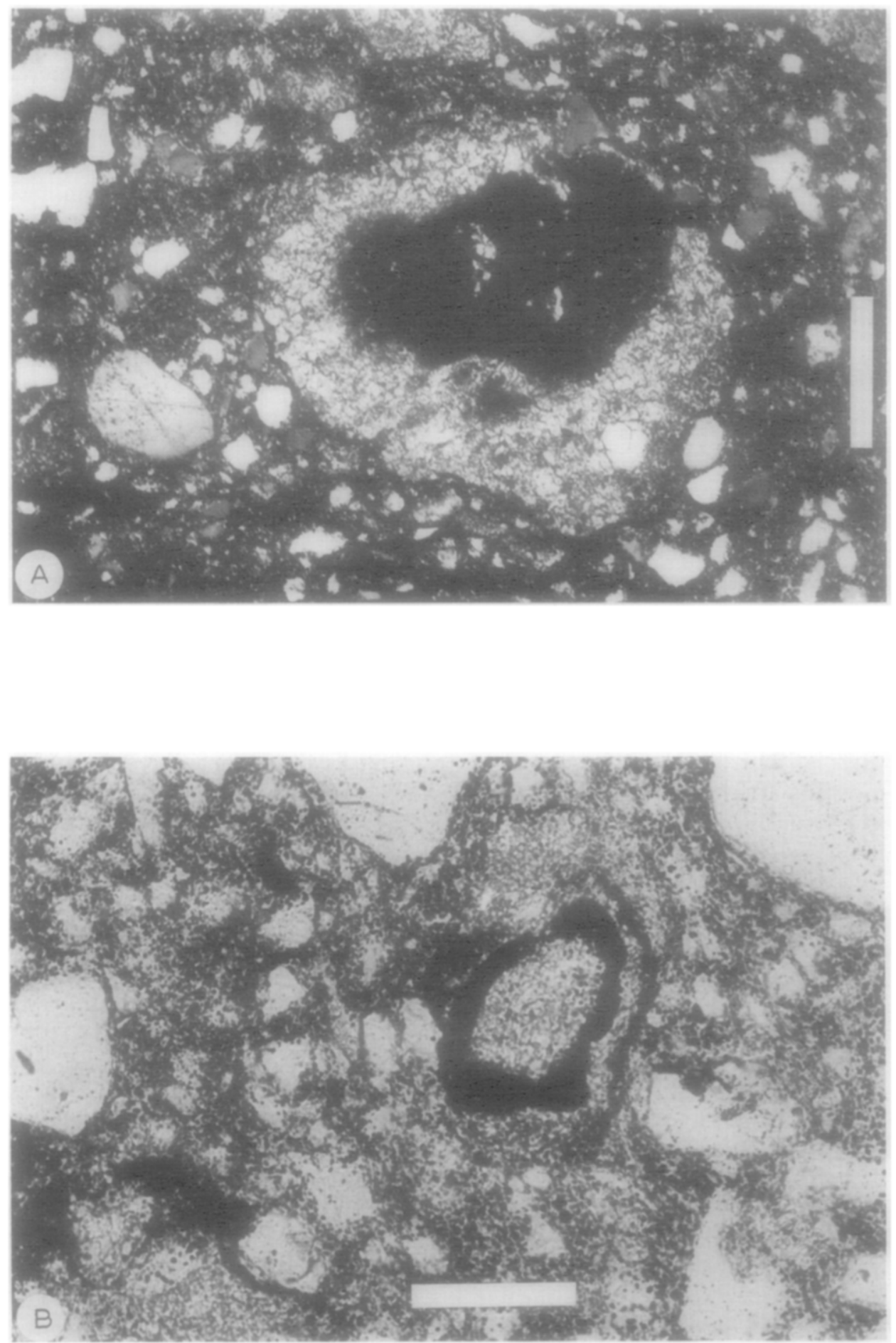

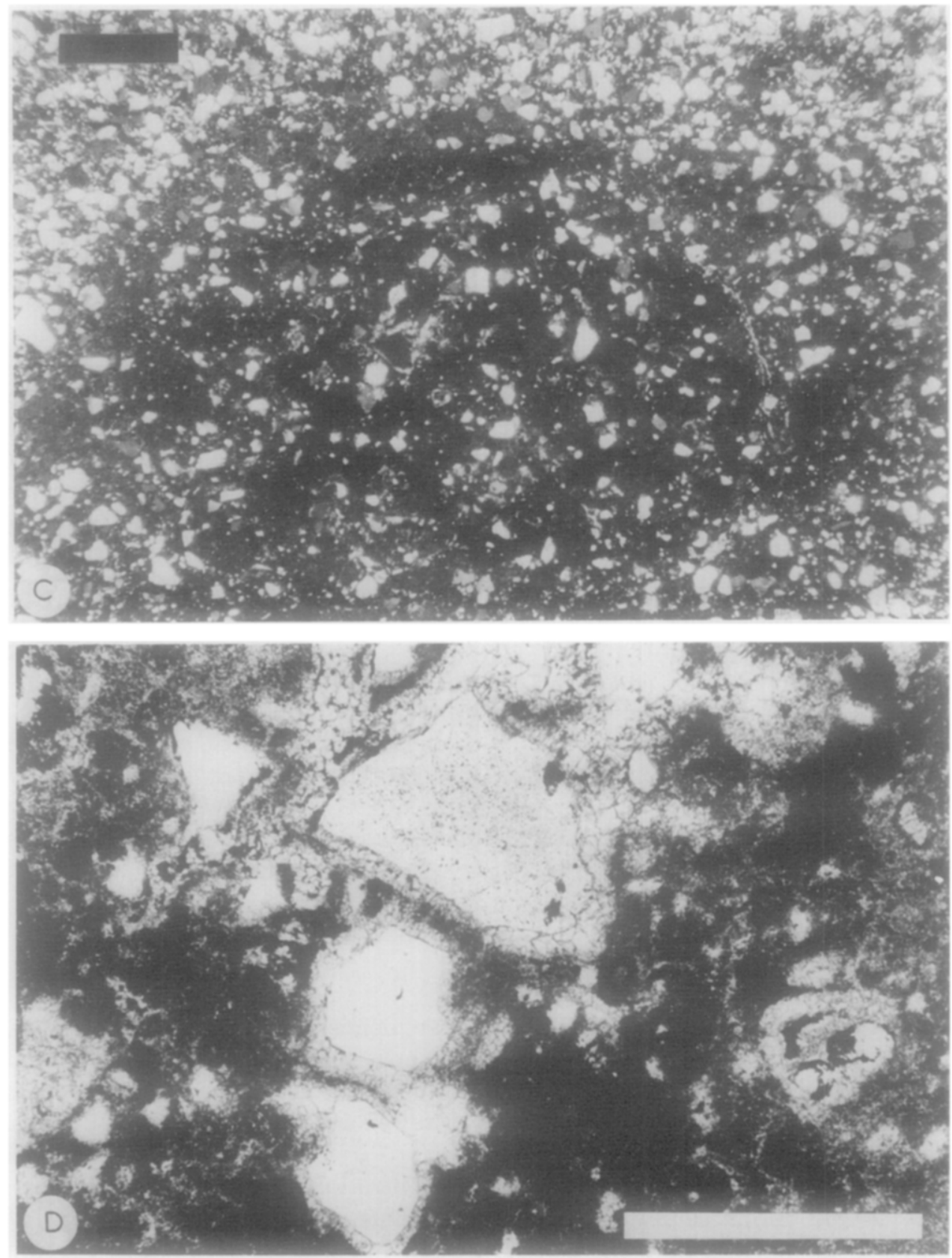

Fig. 8. A. Compound glaebule with ferric nucleus in a wacke. Crossed nicols. Sample TF86, Location 4 . Scale bar $=0.2 \mathrm{~mm}$. B. Small concentric laminated compound ferric-calcite glaebule. Plane polarized light. Sample TF87, Location 4 . Scale bar $=0.2 \mathrm{~mm}$. C. Large concentric laminated compound ferric-calcite glaebule with glaebular halo and high content of clastic quartz grains. Partly crossed nicols. Sample TI39, Location 2. Scale bar = $1 \mathrm{~mm}$. D. Detail of Fig.8C: calcite-coated quartz grains, i.e. calcitans, inside the glaebule. Plane-polarized light. Sample TI39, Location 2. Scale bar $=0.5 \mathrm{~mm}$. 
that they were not in hydrodynamic equilibrium with the coarse siliciclastics. Frequently they grade outwards into the sediment, possessing a diffuse boundary or a glaebular halo. In contrast, the compound glaebules are often concentrically layered (Fig.8C) with one or more thin haematitic laminae (Fig.8B), or a haematitic nucleus (Fig.8A).

The diffuse glaebular boundaries and the association with mottled host rocks suggest that the redistribution of iron-manganese, which sometimes culminated in the formation of glaebules, can be interpreted as mainly due to pedogenic accretionary processes (Brewer and Sleeman, 1964).

\section{Colour}

Present rock colours vary from greyish-red and pale orange-red, or light to very light grey. The red colouring is caused by the amount of iron-oxides and their distribution. In the clayey-silty matrix of the wackes and in some conglomerates primary pigment, i.e. detrital clay-sized iron-oxides, might have been present. In the arenites, most of the iron compounds were infiltrated as primary matrix content is very low. Subsequently the iron was redistributed by pseudogleying.

After (re)precipitation and subsequent oxidation, the iron oxides were converted into haematite, which constitutes the red pigment; the so-called ageing (Turner, 1980). This conversion to haematite could be partly of pedogenic nature in semi-arid and arid climates (Walker, 1967; Van Houten, 1973; Bown and Kraus, 1981). However, diagenetic conversion of part of the iron compounds and/or haematite into (re)crystallized cement is indicated by replacement of quartz clasts, authigenic quartz overgrowths, and quartz cement by haematite crystals. The present colour distribution is thus the result of penecontemporaneous processes, partly pedogenic, as well as of burial diagenesis.

\section{Calcite and compound glaebules}

In the upper part of the fining-upward sequences, glaebules (sensu Brewer, 1964) are a fairly common feature. The host-rock is usually a greyish-red coloured wacke, and occasionally an arenite. In a few cases reworked nodules and other pedorelicts such as papules (Brewer and Sleeman, 1964; Brewer, 1972) were observed.

Concurrent with, or shortly after the infiltration of iron compounds, calcite supply and precipitation took place. This caused the development of whitish calcite glaebules. The glaebules range in diameter from 0.1 to $1.5 \mathrm{~mm}$ and are massive micritic or microsparitic nodules, or they may alternatively be concentrically laminated. In the latter case they are called concretions (Brewer, 1964). Sometimes the glaebules may be compound, i.e. they may possess some haematitic laminae or a haematite nucleus (Fig.8). The haematite was probably precipitated periodically during reducing conditions in a still-porous calcite nodule (Chakravarty et al., 1982). 
The concentric habit is caused by an alternation of calcitic and hematitic laminae in the compound glaebules or by a slight variation in the size of calcite crystal: the glaebule nuclei are often sparitic while the outer laminae or layer are micritic to microsparitic. In the latter case, the laminations are diffuse and the concentric habit is faint. Most calcite glaebules have a distinct boundary, whilst the larger compound glaebules tend to have diffuse boundaries and glaebular halos (Fig.10).

In the fining-upward sequence (section 2 and 4 ) the number and size of the glaebules increase towards the top. In the uppermost level, the glaebules are clustered together forming calcrete nodules up to $1.5 \mathrm{~cm}$ in size (Fig.9) (Nagtegaal, 1969; Reeves, 1970; Allen, 1974; Steel, 1974). The constituent glaebules are separated from each other by thin films of clayey material where stylolitization may have occurred preferentially during burial diagenesis. Owing to shallow burial compaction or to the stylolitization, several nodules tend to have their long axes parallel to the bedding.

Nodule growth was displacive as indicated by the lower percentage, or even the total absence, of clastic grains inside the nodules. If (quartz) grains are present, an occurrence which is generally restricted to compound glaebules, they may be enveloped by a single calcite crust (Fig. 8D), a feature characteristic of calcrete (Nagtegaal, 1969). This crust, called calcitan (Jongerius and Rutherford, 1979), is composed of wedge-shaped microspar-

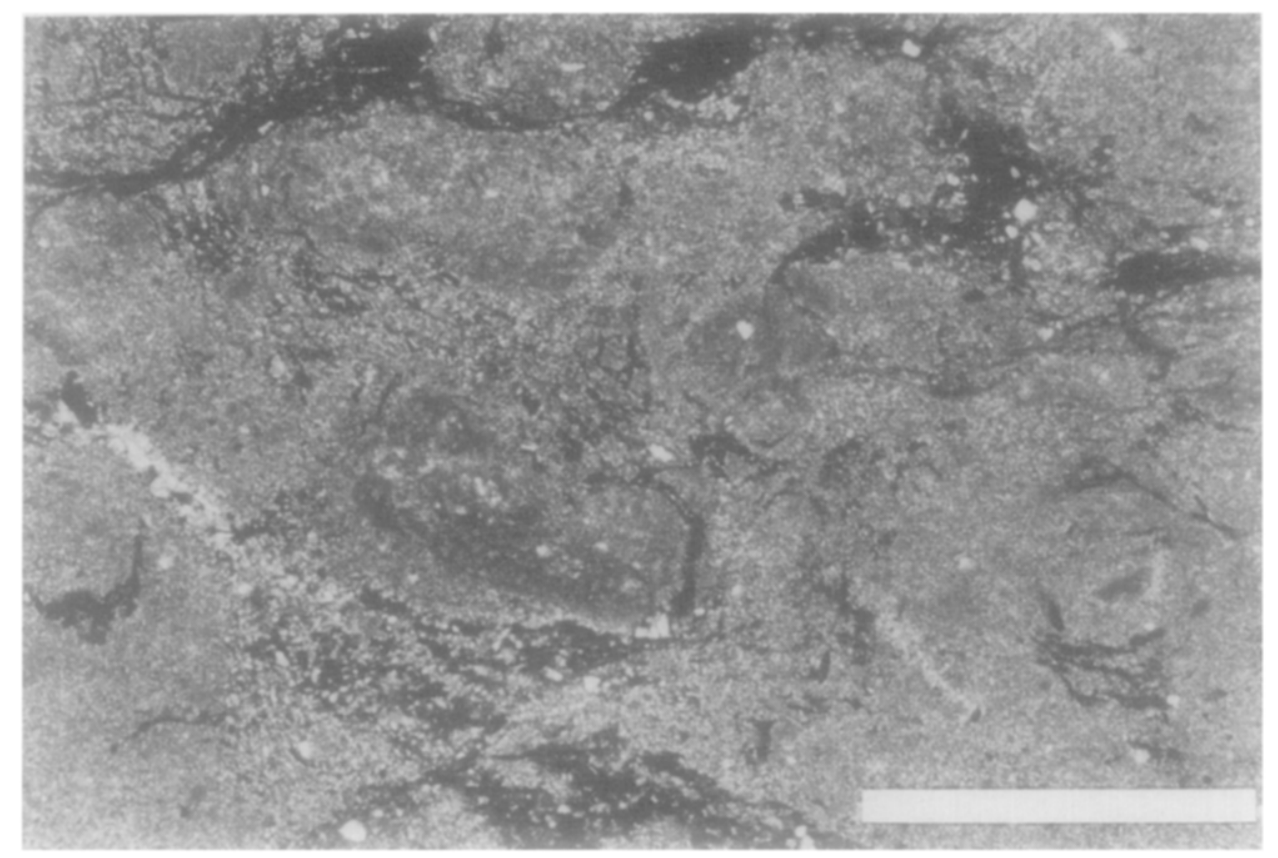

Fig.9. Calcrete nodule with circular cracks and craze planes, composed of coalescent calcite glaebules. Crossed nicols. Sample TI30, Location 2. Scale bar $=1 \mathrm{~mm}$. 


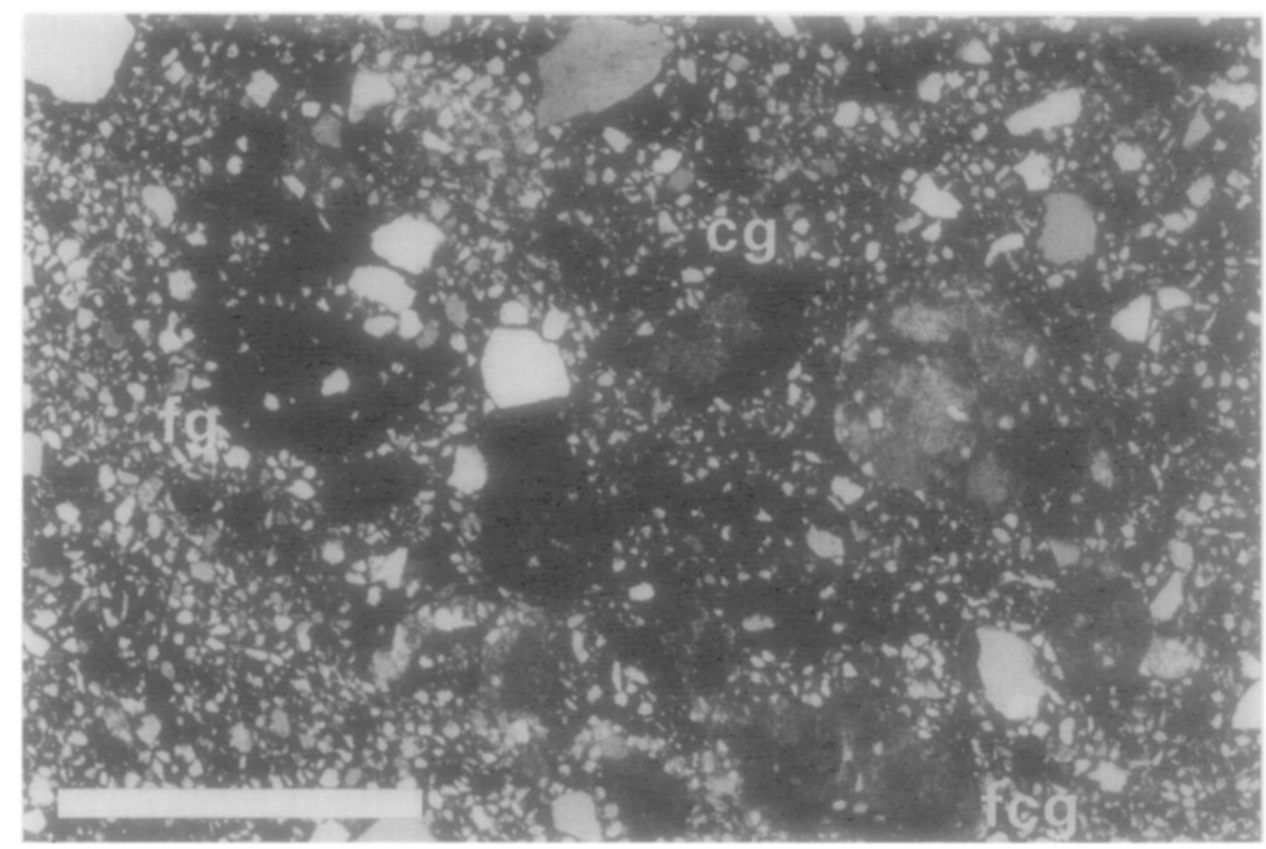

Fig.10. Ferric glaebules with undifferentiated fabric and diffuse boundaries $(f g)$ and some low-Mg calcite glaebules (cg) and compound ferric-calcite glaebules $(f c g)$ in a poorly sorted wacke. Partly crossed nicols. Sample M5, Location 5 . Scale bar $=1 \mathrm{~mm}$.

sized calcite crystals, oriented with their long axes perpendicular to the grain surface.

The larger glaebules may be dissected by curved or irregular cracks, now infilled by microspar-sized calcite, spar-sized calcite, haematite, and occasionally by gypsum-anhydrite. These cracks were caused by desiccation, since evidence of dissolution is absent. Along the margins of the cracks (if calcite filled) the glaebule shows crystal enlargement into microspar or spar. Glaebules and calcrete nodules do not occur together with root tubes.

The fact that calcite glaebules grade into nodular calcrete and display a broad range in size; the displacement of the host rock by the calcite glaebules; the disruption of calcite glaebules by striotubules; the presence of desiccation cracks; and the glaebular halos around several larger compound glaebules all suggest that the glaebules are orthic pedogenic features, i.e. that they are formed in situ during a pre-burial stage.

\section{GENERAL INTERPRETATION AND DISCUSSION}

According to the internal organization into sheet-like or lenticular layers with shallow internal scour-and-fill structures and horizontal or subhorizontal lamination and arrangement of layers in thinning-upward and fining-upward 
sequences, Member 1 is thought to consist of (distal) sheetflood deposits, stream channel deposits and crevasse splay deposits. The arenites in which mechanical infiltration occurred were probably deposited in the interchannel areas or in the abandoned part of a coastal alluvial plain. The fluvial and terrestrial nature of the deposits is confirmed by the root horizons, glaebule horizons, and by the vadose illuviation. That the coastline was in the vicinity appears from some marine intercalations, with a high content of clastic carbonate towards the top of Member 1 . These carbonate grains probably originated from marine lagoonal influxes. Thus it is likely that the pertinent area belonged to the southeastern edge of the Givetian Old Red Continent.

Most of the features, such as the root-horizons and the glaebule horizons as well as the colouration, are arranged parallel to the bedding. Especially in Location 4, several horizons could be traced over a distance of several hundreds of meters. This suggests that the bedding was likewise parallel to the palaeomorphic surface and the associated palaeo-groundwater level. The various processes apparently occurred during the absence of major tectonic movements and erosion (Dorn, 1960; Bless et al., 1980).

Most of the pedogenic features are dispersed throughout the sections and, perhaps with the exception of the fining-upward sequences (section 2 and 4), they never compose a complete palaeosol profile. This may indicate a slow subsidence of a fairly stable continental margin with continuous local reworking of the sediments and soils.

A number of the processes are thus penecontemporaneous but not necessarily pedogenic: in particular the mechanical clay and iron-manganese infiltration. Others are definitely pedogenic and also occurred in the vadose to very shallow phreatic zone: part of the clay and iron-manganese infiltration; the calcite infiltration and segregation, combined with ferro-manganiferous oxides in glaebules and compound glaebules; the separation of ferromanganiferous oxides by gleying. Conversion to haematite is in part a burial diagenetic process.

A low groundwater level is indicated by the process of pseudogleying, which points to an oxidized dry soil (Buurman, 1980), as well as by the infiltration of clay minerals and iron-manganese compounds with downward waterflow (Walker et al., 1978). Furthermore, a low ground-water level is a prerequisite for the formation of nodular calcrete and calcite glaebules, since these are only stable in a largely dry soil. The presence of the calcrete nodule horizons and/or calcite glaebules also indicates a low and highly periodical (seasonal) precipitation with net evaporation and a fairly high temperature (Nagtegaal, 1969). The ferric oxide lamination in the compound glaebules were caused by mobilization of iron (and manganese) compounds during wet and thus reducing periods. Subsequent precipitation occurred after preferential evaporation of still porous calcite nodules. They also point to alternating dry and wet periods (Sehgal and Stoops, 1972; Chakravarty et al., 1982). Apart from the pseudogley, the cracks in the calcrete nodules caused by in situ brecciation also seem to point to an alternate wetting and drying of the 
sediment (palaeosol) (Freytet, 1973). A semi-arid climate is also indicated by the precipitation of calcium sulphates in former burrows and by the occurrence of ferric glaebules (e.g. Gallaher et al., 1974).

However, the calcrete does not progress beyond the first stage of calcrete formation (stage 1 of Leeder, 1975), i.e. small nodules dispersed throughout the host sediment (Wieder and Yaalon, 1982). Furthermore, it does not occur concurrently with illuviated materials and root tubes. Accumulation of pedogenic calcrete is controlled by such factors as time, topography, climate and chemical factors, i.e. the supply of calcium carbonate in case of siliciclastic and non-calcareous sediments. Since the sedimentation rate was very low in this area, enough time was available for the potential formation of calcrete. During the Givetian, a period of approximately $5 \mathrm{Ma}$ (Odin, 1982), $10-70 \mathrm{~m}$ of sediment were deposited in the studied area. When the topographic gradient is too high and/or rainfall is too high, the calcium carbonate constituents are flushed out of the sediment. However, the sedimentary structures suggest shallow, relatively low-energy fluvial channels on a flat coastal alluvial plain. A low relief is also indicated by some marine incursions in Member 1. Thus, a more conclusive explanation of stage 1 of calcrete formation is that the precipitation was somewhat higher than ideal circumstances, as is also suggested by the various levels with traces of vegetation and by the mineralogical composition of the clastics.

The supply of iron and manganese (oxi)hydrates (in solution or bound to clay minerals) and the high mineralogical maturity (Suttner et al., 1981) could be explained by intensive chemical leaching and weathering in the source area. This resulted in the quartzose composition of the clastics.

\section{CONCLUSIONS}

Member 1, constituting the lower part of the Nèvremont Formation, is characterized by the presence of pedogenic features. These are pseudogley, glaebules, nodular calcrete and root horizons.

Early vadose diagenesis and clay and iron-manganese illuviation played an important role. This diagenesis might have been associated in part with palaeosols. Diagenesis and pedogenesis are indicative of a semi-arid climate, while the composition of the sediments and the illuviated iron-manganese compounds suggest intensive weathering in the source area.

Based on the terrestrial character of Member 1, the Old Red Continent extended into the western part of the Vesdre Basin during the earliest Givetian.

The colour of the variegated sediments is of post-depositional nature, i.e. formed partly during pre-burial stage and partly during burial diagenesis.

\section{ACKNOWLEDGEMENTS}

I wish to express my gratitude to P. Buurman, A. J. de Feyter, P. Marks, E. Nickel, S. D. Nio and J. P. A. Stribos for their critical reading of the 
manuscript and their suggestions for improvement. I thank J. Pieters for his help in interpreting the SEM observations. Thin sections were prepared by J. W. de Groot, I. Nussgen, O. H. Stiekema and W. J. Wildenberg. Furthermore, thanks are due to J. A. Schiet for the photographs.

Comparative Sedimentology Division report number 42.

\section{REFERENCES}

Allen, J. R. L., 1974. Studies in fluviatile sedimentation: implications of pedogenic carbonate units, Lower Old Red Sandstone, Anglowelsh outcrop. Geol. J., 9: 181-208.

Bless, M. J. M., Bouckaert, J., Conil, R., Groessens, E., Kasig, W., Paproth, E., Poty, E. and van Steenwinkel, M., 1980. Pre-Permian depositional environments around the Brabant Massif in Belgium, The Netherlands and Germany. Sediment. Geol., 27: 1-81.

Bown, T. M. and Kraus, M. J., 1981. Lower Eocene alluvial paleosols (Willwood Formation, northwest Wyoming, U.S.A.) and their significance for paleoecology, paleoclimatology, and basin analysis. Palaeogeogr., Palaeoclimatol., Palaeoecol., 34: 1-30.

Brewer, R., 1964. Fabric and Mineral Analysis of Soils. Wiley, New York, N.Y., 470 pp.

Brewer, R., 1972. The basis of interpretation of soil micromorphological data. Geoderma, 8: $81-94$.

Brewer, R. and Sleeman, J. R., 1964. Glaebules: their definition, classification and interpretation. J. Soil Sci., 15: 66-78.

Buurman, P., 1980. Paleosols in the Reading Beds (Paleocene) of Alum Bay, Isle of Wight, U.K. Sedimentology, 27: 593-606.

Chakravarty, D. H., Sehgal, J. L. and Dev, G., 1982. Characterization and pedogenic development of $\mathrm{Fe}-\mathrm{Mn}$ glaebules in the alluvium-derived soils of Assam, India. Pédologie, XXXII: $39-51$.

Coen-Aubert, M., 1974. Le Givetien et le Frasnien du Massif de la Vesdre. Stratigraphie et paléogéographie. Acad. R. Belg., Mem. Cl. Sci., Collect. 4. 2e Ser., T. XVIII, 146 pp.

Dorn, P., 1960. Geologie von Mitteleuropa. Schweizerbart, Stuttgart, 488 pp.

Freytet, P., 1973. Petrography and paleo-environment of continental carbonate deposits with particular reference to the Upper Cretaceous and Lower Eocene of Languedoc (Southern France). Sediment. Geol., 10: 25-60.

Gallaher, R. N., Perkins, H. F. and Tan, K. H., 1974. Classification, composition, and mineralogy of iron glaebules in a southern coastal plain soil. Soil Sci., 117: 155-164.

Heald, M. T. and Larese, R. E., 1974. Influence of coatings on quartz cementation. J. Sediment. Petrol., 44: 1269-1274.

Jongerius, A. and Ru therford, G. K., 1979. Glossary of Soil Micromorphology, Wageningen, $138 \mathrm{pp}$.

Kasig, W. and Neumann-Mahlkau, P., 1969. Die Entwicklung des Eifeliums in Old-RedFazies zur Riff-Fazies im Givetium und unteren Frasnium am Nordrand des Hohen Venns (Belgien-Deutschland). Geol. Mitt., 8: 327-388.

Leeder, M. R., 1975. Pedogenic carbonates and floodsediment accretion rates: a quantitative model for alluvial arid zone lithofacies. Geol. Mag., 112: 257-270.

McPherson, J. G., 1979. Calcrete (Caliche) paleosols in fluvial redbeds of the Aztec siltstone (Upper Devonian), Southern Victoria Land, Antarctica. Sediment. Geol., 22: 267-285.

Morad, S., 1983. Diagenesis and geochemistry of the Visingsö Group (Upper Proterozoic), Southern Sweden: a clue to the origin of color differentiation. J. Sediment. Petrol., 53: $51-65$.

Nagtegaal, P. J. C., 1969. Microtextures in recent and fossil caliche, Leidse Geol. Meded., 42: 131-142.

Odin, G. S., 1982. The Phanerozoic time scale revisited. Episodes, 1982, (3): 3-9. 
Oxtlam, D., 1980. Erkennung und Bedeutung fossiler Bodenkomplexe in Locker- und Festgesteinen. Geol. Rundsch., 69(2): 581-593.

Reeves, C. C., 1970. Origin, classification, and geological history of caliche on the southern High Plains, Texas and eastern New Mexico, J. Geol., 8: 352-362.

Sehgal, J. L. and Stoops, G., 1972. Pedogenic calcite accumulation in arid and semi-arid regions of the Indo-Gangetic plain of erstwhile Punjab (India) - their morphology and origin. Geoderma, 8: 59-72.

Steel, R. J., 1974. Cornstone (fossil caliche) - its origin, stratigraphy, and sedimentological importance in the New Red Sandstone, western Scotland. J. Geol., 82: 351-369.

Suttner, L. J., Basu, A. and Hack, G. H., 1981. Climate and the origin of quartz arenites. J. Sediment. Petrol., 51: 1235-1246.

Teruggi, M. E. and Andreis, R. R., 1971. Micromorphological recognition of paleosolic features in sediments and sedimentary rocks. In: D. H. Yaalon (Editor), Paleopedology: Origin, Nature and Dating of Paleosols, Jeruzalem, pp. 161-172.

Tsien, H. H., 1974. Paleoecology of Middle Devonian and Frasnian in Belgian. In: J. Bouckaert and M. Streel (Editors), International Symposium on Belgian Micropaleontological limits. Geol. Surv. Belgium Publ. No. 12, 56 pp.

Turner, P., 1980. Continental red beds. Developments in Sedimentology, 29. Elsevier, Amsterdam, $561 \mathrm{pp}$.

Van Houten, F. B., 1973. Origin of red beds: a review - 1961-1972. Annu. Rev. Earth Planet. Sci., $1: 39-61$.

Walker, T. R., 1967. Formation of red beds in modern and ancient deserts. Geol. Soc. Am. Bull., 78: 353-368.

Walker, T. R., Waugh, B. and Crone, A. J., 1978. Diagenesis in first-cycle desert alluvium of Cenozoic age, southwestern United States and northwestern Mexico. Geol. Soc. Am. Bull., 78: 353-368.

Wieder, M. and Yaalon, D. H., 1982. Micromorphological fabrics and developmental stages of carbonate nodular forms related to soil characteristics. Geoderma, 28: 203-220.

Ziegler, P. A., 1978. North-Western Europe: tectonics and basin developments. In: A. J. van Loon (Editor), Key-notes of the Megs-II (Amsterdam 1978). Geol. Mijnbouw, 57: $589-626$. 